\title{
THE LAW AND EQUITY REFORM BILL AND FEDERAL EQUITY RULES; THEIR EFFECT IN FEDERAL PROCEDURE.
}

Sections 274a and 274b of the Law and Equity Bill, passed by Congress March 3, I9I5, were drawn by a committee of the American Bar Association. Section 274c (not discussed in this paper) relating to jurisdictional amendments in removal cases, was proposed in I9I2 by Judge Clayton, then in Congress, now United States District Judge for the Northern and Middle Districts of Alabama. The pertinent constitutional provisions, and the rules and statutes, are here set out in full. Equity Rules 22 and 23 partially cover the same ground.

"The judicial power shall extend to all cases, in law and equity, arising under this Constitution, the laws of the United States, and treaties made or which shall be made under their authority." Constitution, sec. 2 , art. 3 .

"In suits at common law, where the value in controversy shall exceed twenty dollars, the right of trial by jury shall be preserved, and no fact tried by a jury shall be otherwise re-examined in any court of the United States than according to the rules of the common law." Seventh amendment to the Constitution, adopted A. D. I79I.

"Suits in equity shall not be maintained in any court of the United States in any case where a plain, adequate and complete remedy may be had at law." Sec. 267 , Judicial Code, reënacting Section 723, R. S., originally passed Sept. 24, I789.

"Sec. 274a. That in case any of said courts shall find that a suit at law should have been brought in equity or a suit in equity should have been brought at law, the court shall order any amendments to the pleadings which may be necessary to conform them to the proper practice. Any party to the suit shall have the right, at any stage of the cause, to amend his pleadings so as to obviate the objection that his suit was not brought on the right side of the court. The cause shall proceed and be determined upon such amended pleadings. All testimony taken before such amendment, if preserved, shall stand as testimony in the cause with like effect as if the pleadings had been originally in the amended form." 
"Sec. 274b. That in all actions at law equitable defenses may be interposed by answer, plea, or replication without the necessity of filing a bill on the equity side of the court. The defendant shall have the same rights in such case as if he had filed a bill embodying the defense of seeking the relief prayed for in such answer or plea. Equitable relief respecting the subject matter of the suit may thus be obtained by answer or plea. In case affirmative relief is prayed in such answer or plea, the plaintiff shall file a replication. Review of the judgment or decree entered in such case shall be regulated by rule of court. Whether such review be sought by writ of error or by appeal the appellate court shall have full power to render such judgment upon the records as law and justice shall require." Act of March 3, I9I5, U. S. Compiled Statutes, secs. 125Ia, 125 Ib, $3^{8}$ U. S. Stat. at Large, 956.

"If at any time it shall appear that a suit commenced in equity should have been brought as an action on the law side of the court, it shall be forthwith transferred to the law side and be there proceeded with, with only such alteration in the pleadings as shall be essential." Equity Rule 22, promulgated Nov. 4, I9I2.

"If in a suit in equity a matter ordinarily determinable at law arises, such matter shall be determinable in that suit according to the principles applicable, without sending the case or question to the law side of the court." Equity Rule 23, Nov. 4, I9r2.

The seventh amendment and the act of 1789 (sec. 267) may be regarded as contemporaneous provisions, since the amendment was submitted to the states about the same time as the adoption of the statute. The latter has been regarded by the courts as having for its main object the preservation of the right of trial by jury in common law cases. ${ }^{1}$ The seventh amendment is in force in all the organized territories. ${ }^{2}$

The general purpose and spirit of these provisions is plain. Plaintiff is not to be turned out of court because he has misconceived the nature or form of his action; that arbitrary and unjust rule has been swept away. It is true that plaintiff might get some benefit from the doctrine of waiver, under certain conditions, but that doctrine was never carried to its logical extent,

${ }^{2}$ Green v. Turner, 98 Fed. 756.

${ }^{2}$ Kennon $V$. Gilmer, I3I U. S. 22, 28, 9 Sup. Ct. 696, 33 L. ed. IIo; Thompson v. Utah, ijo U. S. 343 , is Sup. Ct. 620,42 L. ed. I061; Dill v. Ebey, infra. 
and afforded only partial relief, as will be seen further on. Whether full relief will result from the new statute depends entirely on the liberality or strictness to be applied by the courts.

Two important questions arise under the new practice, (I) Whether the cause of action may be changed by amendment after the statute of limitations has run, from equity to law, or vice versa; (2) How far the present rules as to waiver have been modified. The situation may be illustrated by cases taken from the former practice: An insurance company held a mortgage against one Schurmeir. The latter died, and administration was taken out. The probate court allowed six months to file claims, and the state statute permitted the time to be extended, by application showing equitable reasons within twelve months thereafter. After the six months had expired, but within the additional twelve months, the company obtained a deficiency judgment on its mortgage claim. It might then have applied either in the probate court or the federal circuit court (the latter having jurisdiction by diverse citizenship) on the equity side, for an extension of time and leave to file. Instead of taking this course it commenced an action at law in the federal court, after such suit was barred by the six months limit. After its complaint had been twice dismissed by the circuit court of appeals application was made to transfer the case to the equity side, to amend, and apply for an extension of time to file. The right to do this was finally sustained, one of the three judges dissenting on the ground that the amendment changed the cause of action after the statute had run. ${ }^{3}$ As the Supreme Court had held in Union Pacific Railway $v$. Wyler that amendments changing the cause of action are not allowable after limitation run, the Schurmeir case stands on narrow ground. But section 274a provides that "any party to the suit shall have the right, at any stage of the cause, to amend his pleadings so as to obviate the objection that his suit was not brought on the right side of the court." This is broad and explicit, and the statute liberally remedial.

${ }^{3}$ Schurmeier v. Connecticut Mutual, r24 Fed. 865,60 C. C. A. 51; I37 Fed. 42,69 C. C. A. 22; 17I Fed. I, 96 C. C. A. 107. The discussion by Judge Hook, who wrote the majority opinion, and Judge Sanborn, dissenting, is clear and full.

4 I58 U. S. 285 , 15 Sup. Ct. 877,39 L. ed. 983 . This decision is considerably limited in Mo., Kan. \& Tex. Ry. v. Wulf, 226 U. S. 570, 33 Sup. Ct. r35, 57 L. ed. 355 . 
In respect to the effect of the Law and Equity Bill on the doctrine of waiver of the right to the legal remedy by defending in equity, or vice versa, an extreme situation may be referred to, one often met in the federal decisions, that of equitable ejectment. A bill to quiet title is filed by one out of possession against one in possession, these facts appearing on the face of the bill. Ejectment is the proper remedy; equity has no jurisdiction, and defendant has a constitutional right to a jury trial. Issue is joined without objection. The proof consists entirely of written instruments, no question of fact for a jury being presented, and there is a decree for plaintiff. On appeal defendant for the first time raises the question of adequate remedy at law. Under the practice prevailing before the new rules and statute the appellate court would have ordered a dismissal ${ }^{B}$ because equity had no jurisdiction. If ejectment had been brought the parties might have waived a jury trial, and in any event there was nothing for a jury to try. The same judge would have tried the case, and in substantially the same way; but because plaintiff had misconceived his remedy dismissal was the only alternative. No matter of substance was involved, but plaintiff must go out of court on a pure technicality. Meanwhile the statute of limitations might have run, so that plaintiff was deprived of all remedy whatsoever. If the Law and Equity Bill shall be construed to require an amendment in such case (instead of a dismissal), and to change the practice to that extent only, not much will have been gained. But it seems that the courts will be inclined to extend this remedial legislation to matters of substance, and give it the full beneficial effect to which it seems to be entitled. ${ }^{. a}$

WATVER OF THE RIGHT TO A TRIAL AT LAW.

A proper consideration of the question whether the doctrine of waiver is affected by the remedial legislation in question makes it necessary to determine just how far the federal courts have heretofore applied that doctrine to equity cases in which there was, or was claimed to be, an adequate remedy at law, and to cases at law when the proper remedy was an equitable

\footnotetext{
${ }^{5}$ Lezeris v. Cocks and Hicks v. Babin, infra.

'Reynes v. Dumont, I30 U. S. 354, 9 Sup. Ct. 486, 32 I. ed. 934; Singer S. M. Co. v. Benedict, 229 U. S. 48I, 33 Sup. Ct. 942,57 L. ed. 1288.

${ }^{\circ}$ United States $v$. Illinois Surety Co. and Dill $v$. Ebey, both fully stated on a later page. Schurmeier v. Connecticut Mutual, supra.
} 
one. There are a very large number of decisions on the subject, only the more important ones being here referred to.

The general and rather indefinite rule on the subject has been that there is no waiver in cases lying outside the equity jurisdiction, but in those belonging to the class over which equity has jurisdiction the objection that the remedy at law is adequate is waived unless taken at an early stage, by motion, suggestion, plea or answer, or unless the court takes notice of the defect, by action sua sponte.

Actions to recover the possession of land in the occupation of the defendant are essentially legal in character, having no equit able feature whatever, and there can therefore be no waiver by failing to raise the question. The court may at any time, upon its own motion, take notice of the objection and dismiss the suit. ${ }^{7}$ If the court as an equitable tribunal is not competent to grant the relief sought, and as such is without jurisdiction of the subject matter, there can be no waiver. ${ }^{8}$

A like rule has been applied to cases where plaintiff's demand is for money damages, either contract or tort, apart from some recognized ground of equity jurisdiction, such as trust or accounting. ${ }^{9}$

\footnotetext{
${ }^{7}$ A leading case is Lewis $v$. Cocks, 23 Wall. $466,23 \mathrm{~L}$. ed. 70, one of equitable ejectment, in which it was also alleged that defendant had practiced a gross fraud upon plaintiff, which was not proven. Another like case often approved is Hipp v. Babin, I9 How. 271, 15 L. ed. 633, where plaintiff sued in equity to recover the possession of land, with an account of the rents and profits. The court held that it was the universal practice to dismiss bills grounded on a merely legal title, where there was no allegation as to partition, equitable accounting, discovery, or multiplicity of suits.

${ }^{8}$ Brown v. Lake Superior Iron Co., I34 U. S. 530, Io Sup. Ct. 604, 33 L. ed. IO2I, a case of a creditors' suit brought without first having exhausted the remedy at law. A waiver was held to exist.

- Brown v. Fletcher, 206 Fed. 461, 124 C. C. A. 367, 2d Circuit, a suit to recover a fund from a testamentary trustee. A leading case is Scott $v$. Neely, I40 U. S. I06, II Sup. Ct. 7I2, 35 L. ed. 358 , where it is said:

"All actions which seek to recover specific property, real or personal, with or without damages for its detention, or a money judgment for breach of a simple contract, or as damages for injury to person or property, are legal actions, and can be brought in the federal courts only on their law side. Demands of this kind do not lose their character as claims cognizable in the courts of the United States only on their law side, because in some state courts, by virtue of state legislation, equitable relief in aid of the demand at law may be sought in the same action. Such blending of remedies is not permissible in the courts of the United States."
} 
Suits for patent infringement may be brought in equity while the patent is still in force, for an injunction and account of profits, and at law either before or after the patent has expired, for damages. If the patent is about expiring an equity suit may be begun if there be time to obtain a temporary injunction according to the rules and practice of the court; otherwise the suit should be at law. As to suits brought before expiration the objection of an adequate remedy at law is waived if not raised at the outset.10 If the recovery of damages and profits is the real object of the suit, the prayer for injunction being merely a subterfuge, the case will be transferred to the law docket under Rule 23.11

In other cases also, injunction suits may be brought where equity gives no remedy, as in the case of unconstitutional taxation, unless irreparable injury or other distinct ground of equitable jurisdiction appears. Therefore there is no waiver, and the objection may be made for the first time in the' appellate court. ${ }^{12}$

In contrast with the decisions referred to there is another class in which the subject matter is of a kind over which equity has general jurisdiction, but where plaintiff has an adequate remedy at law. Such cases generally fall within the concurrent jurisdiction, where the right or estate of plaintiff, and the remedy, are both legal, but such remedy is not a full, adequate and complete one. ${ }^{13}$ In this class the rule has been that while

${ }^{10}$ Clark v. Wooster, rig U. S. 322, 7 Sup. Ct. 217, 30 L. ed. 392. An equity suit for damages and profit brought after the patent expires, but where no objection is raised until the case is reached on appeal, is a good test of the question whether there must be a reversal under the new rules and law of 1915. The question does not often come up, because the objection is generally raised at the outset. The leading case on the juris-diction is Root v. Lake Shore \& Mich. Cent. Ry. Co., I05 U. S. I89, $26 \mathrm{~L}$. ed. 975 . The Allen case, cited below, was a reversal under similar circumstances.

${ }^{11}$ Goldschmidt Thermit Co. v. Primos Chemical Co., 216 Fed. 382. This suit was before the District Court again (225 Fed. 769) and the rule of practice in patent cases, as modified by the Equity Rules, fully discussed by Judge Dickinson.

${ }^{12}$ As the entire record failed to show complainant entitled to any injunction the decree was reversed on appeal. Allen v. Pullman's Pal. Car Co., I39 U. S. 658, II Sup. Ct. 682, 35 L. ed. 303; Singer Serering M. Co. v. Benedict, 229 U. S. 481,33 Sup. Ct. 942,57 I. ed. I288.

${ }^{23} \mathrm{~A}$ good illustration is contribution among co-sureties, where one has paid more than his share. Having paid out money at the instance of his co-sureties, his right to reimbursement is legal, as well as his right to sue each of them in assumpsit. But such remedy is not so prompt and efficient as an equitable suit for contribution. 
the court for its own protection might prevent matters properly cognizable at law from being drawn into chancery at the pleasure of the parties interested, yet where the subject matter belonged to a class over which a court of equity had jurisdiction, and the objection was not made until the hearing on appeal, ${ }^{14}$ or until the hearing in the trial court, ${ }^{15}$ the court would apply the rule of waiver.

This rule obviously has no application to suits which cannot be maintained under any circumstances, such as ejectment on an equitable title, judicial enforcement of a ministerial or legislative function, such as levying or collecting taxes, or making rates for transportation, or for furnishing light or power. In such cases either a bill in equity or complaint or declaration at law is bad on its face, ${ }^{16}$ and may be dismissed at any stage. Equity Rule 23 has no application to a bill in equity stating no cause of action in equity. ${ }^{17}$

\footnotetext{
${ }^{14}$ Reynes v. Dilmont, 130 U. S. 354, 395, 9 Sup. Ct. 486, 32 L. ed. 934 ; Tyler v. Savage, I43 U. S. 79, 97, 12 Sup. Ct. 304, 36 L. ed. 82; Southern Pac. R. Co. v. United States, 200 U. S. 341, 26 Sup. Ct. 296,50 L. ed. 507.

${ }^{15}$ In the earlier cases the waiver rule was generally applied only in appellate courts. In I 889 Judge Blatchford dismissed a suit on the hearing where the bill disclosed no right to sue in equity. Mills v. Knapp. 39 Fed. 592. In Dederick v. Fox (C. C.), 56 Fed. 7I4, a similar rule was decided. There seems to be no good reason why a trial court should not apply the rule, when the objection is not made until final hearing. Waite v. O'Neil, 72 Fed. 348.

${ }^{15}$ A leading case of equitable ejectment is Fussell v. Gregg, II3 U. S. 550, 5 Sup. Ct. 631, 28 L. ed. 993, where it was decided that a bill to recover possession of land, based on an equitable title under a state land warrant was insufficient. Plaintiff must get in the legal title and then sue at law. Among the taxing cases are Rees v. City of Watertown, 19 Wall. 107, 22 L. ed. 72; Thompson v. Allen County, II5 U. S. 550, 6 Sup. Ct. 140, 29 L. ed. 472; Street Grading District v. Hagadorn, 186 Fed. 45I, ro8 C. C. A. 429 , 8th Circuit, and Preston v. Sturgis Milling Co., 183 Fed. I, I05 C. C. A. 293. The following decisions illustrate the distinction between judicial and legislative power: Atchison, T. \& S. F. R. Co. v. Denver \& N. O. R. Co., Iro U. S. 682, 4 Sup. Ct. I92, 28 L. ed. 297; Express Cases, II7 U. S. 1, 6 Sup. Ct. 628, 29 L. ed. 791; Prentis v. Atlantic Coast Line, 2II U. S. 210, 226, 29 Sup. Ct. 68, 53 L. ed. I50; Cumberland T. \& T. Co. v. United Electric R. Co., 42 Fęd. 273, I2 L. R. A. 544; Peoria Water Works Co. v. Peoria Ry. Co., I8r Fed. 990, I004. Of a similar nature in this respect are suits to set aside a will or its probate, unless authorized by local law. Broderick's Will, 21 Wall. 503, 22 L. ed. 509; Beyer v. LeFevre, I86 U. S. II4, 22 Sup. Ct. 765, 46 L. ed. I080.

${ }^{17}$ So held in a suit to establish a mechanic's lien in which the complaint or bill was insufficient on the merits. Lindon Inv. Co. v. Houstain Bros. Co., 221 Fed. I78, - C. C. A. -
} 
It has also been decided that a suit brought on the law side which should properly have been on the equity side may be rightfully dismissed, or remanded for amendment under the Law and Equity $\mathrm{Bill}^{18}$ or under the preexisting law, as in the Schurmeier case.

Before the change made by the rules and the Law and Equity Bill equitable defenses were sometimes sought to be enforced in actions at law, as where plaintiff in a personal injury suit attempted to show that a release of damages made by him was invalid for unfairness, fraud, or want of his capacity. The same rule of waiver was applied as in the cases before discussed.10 Equitable defenses affecting the right of possession may be shown in ejectment because it is a possessory action. ${ }^{20}$

${ }^{18}$ Smith v. American Nat. Bank, 89 Fed. 832, 32 C. C. A. 368, 8th Circuit; Illinois Surety Co. v. United States, - Fed. $-\longrightarrow$ C. C. A. - 7th Circuit. The latter was a suit at law brought on a bankruptcy depositary bond given under section $6 r$ of the Bankrupt Act. Section 5oh of the act provides for suit on such bonds in the name of the United States for the use of any interested person. It was decided that such remedy is necessarily an equitable one in case of a failure of the bank, in which all beneficiaries can be brought in and bound by a single decree. If each trustee, receiver, or depositor could bring an action at law for his own benefit, "the possible diversity of opinion as to what that share is might result either in subjecting the defendant to judgments in excess of the penalty or in defeating the just claims of the later litigants." A judgment at law for the full penalty and interest was reversed, and remanded with leave to amend and proceed under sec. $274 \mathrm{a}$.

The same court, in a suit at law brought on a bond given under the federal public improvement statute, held that the issues could be determined as well in a court of law as in equity, where the trial was by jury, but the jury had been discharged by the court because both parties had moved for a directed verdict, thereby asserting that there was no disputed question of fact. The trial judge made a full finding of facts, which were undisputed. It was of no practical importance whether a court of law or equity was the proper form, as there was little or nothing for a jury to pass upon. A court of law not being entirely without jurisdiction, the ordinary rule of waiver was also applied. United States v. Illinois Surety Co., — Fed. -, - C. C. A. -, 7th Circuit.

${ }^{19}$ Union Pac. R. Co. v. Harris, 63 Fed. 800, I2 C. C. A. 598; Union Pac. R. Co. v. Whitney, I98 Fed. 784 , II7 C. C. A. 392, 8th Circuit. These were cases of such fraud or incapacity as rendered the release not merely voidable but void. They were not cases of consent procured by fraud. In Standard Portland Cement Corp. v. Evans, 205 Fed. I, I25 C. C. A. r, it was decided that the equitable defense of fraud in procuring the corporate assent to a contract could not be set up in an action at law on the contract, and that jurisdiction of such a defense could not be conferred by consent or waiver. See Columbia Digger Co. v. Rector, 215 Fed. 6r8.

${ }^{20}$ Dickerson v. Colgrove, 100 U. S. 578,25 L. ed. $6 \mathrm{18}$. 
Though many other cases might be cited on waiver it is thought the foregoing accurately presents the scope of the rule as heretofore applied in the national courts.

So far as the remedial rules under consideration have come before the courts they have been liberally construed, as has been seen. It would seem that the doctrine of waiver should be considerably extended, and made to apply to every case where the parties have, by not claiming it, waived the constitutional right to a jury trial, especially when there are no disputed facts, as in United States $v$. Illinois Surety Co., above stated. The following decision of the Supreme Court is fully stated, and is particularly referred to because of its discussion of the effect of the adoption by Congress of the state code system of procedure, and what constitutes waiver of a jury trial:

In the case of Dill v. Ebey, ${ }^{21}$ a judgment of the Supreme Court of Oklahoma was under review. The suit was originally brought on the equity side of the United States Court for the Western District of Indian Territory to recover an unpaid stock subscription. Defendant raised the question of adequate remedy at law by demurrer, and that he was by the Constitution entitled to a jury trial. The demurrer was overruled in the federal court, and defendant properly saved an exception. Before any further proceeding in the case the state of Oklahoma was organized from the Indian and Oklahoma territories, and the case was thereupon transferred to the state district court for the proper county. Defendant then filed an answer to the merits, alleging that he had paid his subscription. Judgment having been rendered against him, he moved for a new trial on the ground that he was entitled to a jury trial, which he asserted had not been waived. This motion being denied, defendant appealed to the Oklahoma Supreme Court, renewing there his objections as to adequate remedy at law and the right to a jury trial. The contentions were overruled, and the judgment affirmed, and then taken to the United States Supreme Court for review.

The same questions were presented in the Supreme Court, it being assumed that the Enabling Act and Oklahoma constitution preserved to defendant all rights asserted in the case while it was in the territorial court. As to the question of adequate remedy at law it was decided that the statute of Arkansas governed that practice, and not section 723 of the federal statutes,

${ }^{21} 229$ U. S. 199, 33 Sup. Ct. 620,57 L. ed. Ir48. 
for the reason that the act of Congress by which the territorial federal court was created provided that its practice, pleadings and forms of proceeding should conform to those in like causes in Arkansas. That state had adopted the Code of Procedure.

A later act of Congress specially provided that the chapter of the Arkansas code relating to pleadings and practice should be in force in the Indian Territory. This chapter contains the usual code provisions abolishing forms of action, providing for a single form of action, which should be either legal or equitable, and that "An error of the plaintiff as to the kind of proceedings adopted shall not cause the abatement or dismissal of the action, but merely a change into the proper proceedings by an amendment in the pleadings, and a transfer of the action to the proper docket." (It will be seen that this is substantially the same provision as that of the Equity Rules and statute of I9I5.) By another part of the chapter so adopted a defendant might demur for want of jurisdiction of person or subject matter, and that the complaint did not state a cause of action. The Supreme Court say: "We hold that if the demurrer may be deemed an assertion by the defendant of a right under $\S 723$, Rev. Stat., to have the case determined in equity (sic), yet that section was so plainly inapplicable to the practice in the territorial court that no substantial federal question is raised, such as would warrant a review here under $\S 709$, Rev. Stat."

It was also held that the right to a jury trial, if it ever existed, was waived by the demurrer in the state court, which was an admission of the facts pleaded. "Indeed," say the court, "since a demurrer has the necessary effect of admitting the facts alleged in the complaint, a demand for a trial by jury is quite incongruous, for a jury has no function to perform when the facts are admitted." Finally it was decided that no federal question was properly raised; and the writ of error was dismissed.

Rule 23 , providing that a matter ordinarily determinable at law arising in an equity suit shall be determined therein without sending the matter to the law side, does not authorize the joinder of legal and equitable causes of action in the same bill, especially in view of Rule 26 , authorizing the joinder of equitable causes only. ${ }^{22}$

\footnotetext{
${ }^{22}$ Bucyrus Co. v. McArthur, 219 Fed. 266, deciding also that Rule 23 obviously relates "only to auxiliary matters of legal cognizance which may arise in the determination of an equity cause."
} 
ENGLISH PRACTICE INAPPLICABLE.

The English rules or orders of the Supreme Court of Judicature, adopted under the Judicature Act of 1873 , relating to "Transfers and Consolidation," are analogous to Equity Rules 22 and 23, and the Law and Equity Bill, but actions of all kinds have been in England so thoroughly fused that judicial construction by its courts has very little application in the federal courts, where actions at law, in equity and admiralty, are still so fully kept separate, as they must be under the Constitution. His Majesty's High Court of Justice is now vested with all the jurisdiction formerly exercised by the High Courts of Chancery and Admiralty, the common law courts of King's Bench, Common Pleas and Exchequer, the Divorce Court, and various other courts and commissions. The High Court is required to enforce legal and equitable rights and estates, equitable and legal counterclaims and defenses, not only against or in favor of the parties, but also against third persons who are served with notice of the suit, whether residents of the United Kingdom or not. It is provided that the object of the statutes is that, "As far as possible, all matters so in controversy between the said parties respectively may be completely and finally determined, and all multiplicity of legal proceedings concerning any of such matters avoided." When there is any conflict or variance between the rules of equity and the rules of the common law with respect to the same matter, the rules of equity are to prevail, and there is a similar provision making the rules of admiralty paramount.

By order $3^{6}$ (Rule 3 ) it is provided that equity cases shall be tried without a jury unless the court or a judge shall otherwise order.

"The twofold system of jurisdiction at law and in equity was put an end to by the Judicature Act, I873. The general scope of the act was to enable a suitor to obtain by one proceeding in one court the same ultimate result as he would previously have obtained either by having selected the right court, as to which there was frequently a difficulty, or after-as was sometimes necessary-having been in two courts in succession. ${ }^{23}$ "It is not provided by the act that legal and equitable rights shall be treated as identical; and the same distinction exists between legal and equitable estates as before the act."24

Madison, Wrsc.

A. L. SANBorN.

Halsbury's Lawes of England, vol. 13, p. 6r.

Ibid., 64 . 